\title{
Factors that Influence Computer Science Students' Attitude towards Serious Games in the Classroom
}

\author{
MJ Zeeman \\ DB Jordaan \\ North-West University, Faculty of Economic Sciences and Information Technology \\ PO Box 1174, Vanderbijlpark, 1900, Republic of South Africa \\ Email: Malie.Zeeman@nwu.ac.za
}

\section{Doi:10.5901/mjss.2014.v5n21p413}

\begin{abstract}
The main purpose of serious games is to train or educate. The use of serious games in class has the potential to provide an exciting and effective learning environment. Many studies report that the built-in motivation features of serious games can motivate and inspire students to be problem solvers. Introducing serious games into classroom and the potential value thereof has received wide attention recently. The purpose of this research, therefore, was to identify the factors the influence the perceptions of computer science students towards serious games in class. A quantitative research approach involving the administration of a structured questionnaire to computer science students was used to collect data for the study. Data were collected at two different university campuses. The questionnaire included questions on demographics and attitudes towards serious games in class. The study revealed that computer science students have a positive attitude towards the use of serious games in class and realise the potential benefits of using serious games in class. Factors that influence students' perceptions towards serious games in class were found to be usefulness, ease of use, self-efficacy, help facilitation and enjoyment. Negativity, indicating that some students might be bored and frustrated using serious games in class, was also detected.
\end{abstract}

Keywords: technology; technology expectations; creativity; child development

\section{Introduction}

The literature reveals many definitions of serious games. According to Wikipedia (wikipedia.org) serious games are "simulations of real-world events or processes designed for the purpose of solving a problem." Zyda (2005) define serious game as an intellectual challenge with specific rules played on a computer, while Susi, Johannesson \& Backlund (2007) describe serious games as games used for purposes other than mere entertainment. Ulicsak \& Wright (2010) define serious games as digital games with an educational intention.

Computer games allow for immersive experiences by allowing the player to get close to applicable challenges and actively make decisions while experiencing the consequences (Engenfeldt-Nielsen, 2011). The main purpose of serious games is to train or teach specific predefined skills and knowledge (Ulicsak \& Wright, 2010) using fun and entertainment with immersive experiences (Zyda, 2005).

The focus of serious games should be on problem solving and elements of learning, while fun and enjoyment are also significant (Susi et al., 2007). Whether the focus should be on fun or education when serious games are developed, is not clear from the literature. Zyda (2005) is of the opinion that the main focus should be gaming elements such as the story line, challenges and other entertainment aspects since students can have fun while these elements encourage them to learn. It is important to balance fun, enjoyment and effective learning to ensure successful acceptance of serious games (Kickmeier-Rust \& Albert, 2012).

Studies conducted by many researchers (Wrzesien \& Alcañiz Raya, 2010; Guillén-Nieto \& Aleson-Carbonell, 2012) indicate that serious games have the potential to be significant teaching tools that may provide an exciting and effective learning environment because of their interactive, engaging and immersive activities (Ulicsak \& Wright, 2010; Gee, 2008; Smith, 2007; Shaffer 2005). Despite the rapid growth of the games industry over the past decades, the use of games in education is still limited (Westera, Nadolski, Hummel \& Wopereis, 2008). Traditional learning environments sometimes lack motivational value while the fun and educational elements of serious games may motivate students to learn (Stege, Van Lankveld \& Spronck, 2011).

Serious games provide an excellent opportunity whereby learners could experience and learn in simulated 
environments, which would be difficult in real life due to, for example high cost, time consuming experiences, and consequences due to failure (Susi et al., 2007). Players expect realistic simulations, rich interactive experiences and the opportunity to control the game (Szczesna, Tomaszek and Wieteska, 2011). Immediate results of a player's decisions in digital simulations and the experience of success enhance the learning experience while the entertaining elements encourage students to want to stay involved (Lieberman, 2006). Anxiety levels are reduced and confidence builds due to the fact that in simulations students do not have to fear the consequences when mistakes are made (Szczesna et al., 2011). Positive feedback, hints on how to progress, and a sense of control by actively participating, are some of the aspects that motivates learners to be active participants. The challenging nature of games has the ability to cause players to become totally absorbed in the task at hand in order to do the best they can (Lieberman, 2006). Furthermore, it is claimed that serious games lead to the positive development of a variety skills (Susi et al., 2007). These include the skill to remember essential facts that are required to progress in the game and higher order thinking skills such as problems solving and application of knowledge. Learners develop these skills while playing serious games since they learn by doing rather than being passive listeners (Stanescu, Stefan\& Roceanu, 2011; Lieberman, 2006).

\section{Problem Statement}

Technology is shaping the way in which people learn, communicate, cooperate, think, work, live and form social networks (Klopfer, Osterweil, Groff \& Haas, 2009). Constant engagement and experience with technology make participatory, sensory-rich environments and experiential or discovery-based learning attractive to students (Wrzesien \& Alcañiz Raya, 2010; Devlin-Scherer \& Sardone, 2010; Corriveau \& Wei, 2010). Current students are not attracted to old-fashioned education (Rooney, 2012; Stege et al., 2011; Papastergiou, 2009) because they are almost fully integrated into technology (Sweeny, 2007) and have a preference for active, first-person, experiential learning that is lacking in traditional lectures, but colorfully present in new media technology (Lenhart, Madden \& Hitlin, 2005).

Technology has become an integral part of society and it is necessary to integrate its use in education (Rodgers, 2014). Kurkovsky (2009) argues that the computer science curriculum should stay applicable and relevant to today's reality and there should be a strong connection between computing and students' everyday involvement with technology.

Analysing the literature reveal that the majority of studies regarding the perceptions of learners on the use of serious games in education are focused on younger age groups leaving a lack of empirical evidence supporting the assumptions that students in tertiary education will embrace the idea of serious games in the computer science classroom (Papastergiou, 2009). These studies demonstrate largely positive attitudes of younger age groups towards serious games in class. However, students in tertiary education may have different requirements, views and perceptions. These aspects need to be taken in account when determining the factors that influence the attitude of students towards serious games in the computer science classroom.

\section{Purpose of the Study}

The purpose of this study was to identify the factors that influence the attitude of students in computer science towards serious games in the classroom.

\section{Research Methodology}

A quantitative research approach was used for the study because it provides a quick, inexpensive, efficient and accurate means of accessing the desired information (Zikmund, Babin, Carr \& Griffin, 2010).

\subsection{Sample and Procedure}

The sample in the study consisted of a non-probability convenience sample of students at two universities, one a traditional university and the other a University of Technology, in the Gauteng province of South Africa.

The principal author, who administered the questionnaire personally at the different university campuses, collected data.

\subsection{Research Instrument}

An extensive literature review on serious games and students' perceptions on serious games in class was undertaken. A 
questionnaire, used in the empirical study, was developed to investigate the perceptions of university students on serious games in class.

The questionnaire used to collect data contained two sections. The first requested demographic information of the respondents and the second section investigated participants' perceptions towards serious games in the classroom. The items in the second section were scored on a six-point Likert scale with one denoting strongly disagree, and five referring to strongly agree. The questionnaire was reviewed for content validity by two academics, one being an expert in serious games and the other in quantitative research. To ensure the reliability of the questionnaire a pilot test was conducted on a convenient sample of 40 students. The reliability of the questionnaire was found to be 0.908 .

\subsection{Ethical Considerations}

Participants were informed both verbally and through a covering letter of the purpose of the study. Ethical considerations such as the participants' right to anonymity, confidentiality, privacy or non-participation, informed consent and protection from discomfort, harm and victimisation were adhered to.

\subsection{Data Analysis}

To analyse the data descriptive analysis of the sample composition was undertaken and factor analysis was used to establish the perceptions of students. The Statistical Packages for the Social Sciences (SPSS - version 22) was used to analyse the data.

\section{Results}

\subsection{Demographics}

A total of 580 questionnaires were administered and 569 completed questionnaires were returned of which 22 were discarded due to incomplete or invalid responses. The remaining 547 questionnaires indicate an actual response rate of 94 percent. The traditional university returned 303 valid questionnaires and the university of technology returned 244 valid questionnaires. More male respondents (56.1\%) than female respondents (43.9\%) completed the questionnaire. In terms of the year of study, 21.7 percent of the participants were first-year students, 43.1 percent were second-year students, 31.8 percent were third-year students, while 3.3 percent were in their fourth year of study. When asked to indicate at what age they start playing games 48.2 percent indicated that they start playing games before the age of 12 years while 57.3 percent indicated that they only start to play games on or after their $12^{\text {th }}$ birthday.

\subsection{Exploratory Factor Analysis}

In the first instance, the appropriateness of factorability on the data set was established. The Bartlett's Test of Sphericity and the Kaiser-Meyer-Olkin (KMO) measure of sampling adequacy (MSA) was conducted on the data set. Both these tests $(\mathrm{KMO}=.920$; sig. $=.000)$ indicated that the data were suitable for factor analysis. Principal component analysis (PCA) with varimax rotation was applied to the 33 items in section B of the questionnaire. Varimax rotation, which reapportions variance among factors so that they become relatively equal in importance, was used to simplify factors by maximising the variance loadings across variables (Gillespie, Derevensky \& Gupta, 2007). Using a minimum eigenvalue of one, the PCA extracted six factors, which accounted for 62.34 percent of the overall variance in the scale item scores with two to 7 loadings on each factor. These factors included performance and experience ( 6 items), ease of use (5 items), self-efficacy (7 items), help facilitation (7 items), enjoyment (3 items) and negativity (2 items). Item reliability for each extracted factor was evaluated using Cronbach alpha (a). The factors' internal consistency ranged from 0.919 0.789 for the six factors, which were greater than the recommended significance level of 0.70 (Nunnally \& Bernstein, 1994) indicating an acceptable level of reliability. The rotated component matrix illustrating the resultant factors, eigenvalues and Cronbach alpha reliabilities provided in Table 1. 
Table 1. Rotated factor loading matrix

\begin{tabular}{|c|c|c|c|c|c|c|}
\hline & \begin{tabular}{|c|}
$\begin{array}{c}\text { F1 Performance \& } \\
\text { experience }\end{array}$ \\
\end{tabular} & $\begin{array}{c}\begin{array}{c}\text { F2 Ease of } \\
\text { use }\end{array} \\
\end{array}$ & $\begin{array}{l}\text { F3 Self } \\
\text { efficacy }\end{array}$ & $\begin{array}{c}\text { F4 Help } \\
\text { facilitation }\end{array}$ & \begin{tabular}{|c|} 
F5 \\
Enjoyment \\
\end{tabular} & $\begin{array}{c}\text { F6 } \\
\text { Negativity } \\
\end{array}$ \\
\hline $\begin{array}{l}\text { I think playing games as part of the learning experience in class } \\
\text { cause me to be more productive and do more class related work }\end{array}$ & .767 & .168 & .291 & .093 & .179 & .087 \\
\hline $\begin{array}{l}\text { I think playing games as part of the learning experience in class } \\
\text { improve my performance in the course }\end{array}$ & .752 & .144 & .351 & .071 & .144 & .066 \\
\hline $\begin{array}{l}\text { I think playing games as part of the learning experience in class } \\
\text { improve my logical thinking skills }\end{array}$ & .742 & .193 & .104 & .151 & .209 & .106 \\
\hline $\begin{array}{l}\text { I think playing games as part of the learning experience in class } \\
\text { improve my problem solving skills }\end{array}$ & .726 & .271 & .058 & .092 & .162 & .132 \\
\hline \begin{tabular}{|l} 
think playing games as part of the learning experience in class be to \\
the advantage of my learning experience in class
\end{tabular} & .724 & .211 & .388 & .074 & .188 & .027 \\
\hline \begin{tabular}{|l|} 
think playing games as part of the learning experience in class be \\
useful to enhance learning in class
\end{tabular} & .713 & .211 & .281 & .047 & .241 & .059 \\
\hline It would be easy for me to interact with a game & .177 & .852 & .159 & -.043 & 159 & .070 \\
\hline It would be easy for me to learn how to play a game & .064 & .843 & .169 & -.032 & .134 & .047 \\
\hline $\begin{array}{l}\text { It would be easy for me to be in control of the game to do what I want } \\
\text { it to do }\end{array}$ & .217 & .810 & .152 & -.019 & .166 & .057 \\
\hline \begin{tabular}{|l|} 
It would be easy for me to follow instructions and navigate through \\
the stages of a game
\end{tabular} & .249 & .783 & .147 & -.040 & .111 & .067 \\
\hline It would be easy for me to become skillful at playing games & .269 & .708 & .087 & .017 & .156 & .130 \\
\hline I think it is wise to use games to enhance learning in class & .251 & .271 & .711 & .049 & .287 & .127 \\
\hline $\begin{array}{l}\text { like the idea of playing (serious) games as part of the learning } \\
\text { process in class }\end{array}$ & .153 & .274 & .698 & .000 & .252 & .045 \\
\hline $\begin{array}{l}\text { People who influence my behaviour will think it is a good idea to play } \\
\text { games as part of learning in class }\end{array}$ & .294 & .072 & .674 & .069 & -.097 & .041 \\
\hline $\begin{array}{l}\text { would like to attend classes where games related to class work are } \\
\text { played }\end{array}$ & .357 & .193 & .579 & .039 & .424 & .117 \\
\hline intend to play games related to class work if it is available & .346 & .150 & .526 & .040 & .436 & .087 \\
\hline $\begin{array}{l}\text { People who are important to me will think it is a good idea to play } \\
\text { games as part of learning in class }\end{array}$ & .442 & .061 & .518 & .068 & -.110 & -.059 \\
\hline $\begin{array}{l}\text { Given that I have access to class related games, I predict that I would } \\
\text { use }\end{array}$ & .452 & .151 & .461 & .033 & .382 & .054 \\
\hline $\begin{array}{l}\text { will be able to play a serious game related to class work if someone } \\
\text { shows me how to play the game first }\end{array}$ & -.038 & -.096 & .008 & .783 & -.010 & .187 \\
\hline $\begin{array}{l}\text { will be able to play a serious game related to class work if someone } \\
\text { else help me get started }\end{array}$ & .037 & -.072 & .002 & .730 & -.029 & -.056 \\
\hline $\begin{array}{l}\text { I will be able to play a serious game related to class work if there is } \\
\text { someone around to tell me what to do }\end{array}$ & .097 & .003 & .049 & .712 & .004 & -.255 \\
\hline \begin{tabular}{|l} 
will be able to play a serious game related to class work if I have \\
watched someone else play the game before trying it myself
\end{tabular} & .114 & -.063 & .015 & .692 & .083 & -.211 \\
\hline $\begin{array}{l}\text { I will be able to play a serious game related to class work if I can call } \\
\text { someone for help if I get stuck }\end{array}$ & .166 & .015 & .021 & .665 & .021 & -.047 \\
\hline $\begin{array}{l}\text { I will be able to play a serious game related to class work if I have } \\
\text { played similar games before to do the same class work }\end{array}$ & -.086 & .087 & .056 & .537 & .048 & .253 \\
\hline $\begin{array}{l}\text { will be able to play a serious game related to class work if I have a } \\
\text { lot of time to complete the class work for which the game is provided }\end{array}$ & .241 & .122 & .076 & .435 & -.019 & .114 \\
\hline Playing games as part of the learning experience in class will be fun & .224 & 212 & .099 & .021 & .791 & .167 \\
\hline $\begin{array}{l}\text { Playing games as part of the learning experience in class will be very } \\
\text { pleasant }\end{array}$ & .257 & .222 & .141 & .023 & .783 & .140 \\
\hline $\begin{array}{l}\text { Playing games as part of the learning experience in class will be } \\
\text { enjoyable for me }\end{array}$ & .259 & .256 & .213 & .052 & .752 & .185 \\
\hline $\begin{array}{l}\text { Playing games as part of the learning experience in class will be } \\
\text { frustrating }\end{array}$ & .157 & .127 & .049 & -.070 & .165 & .822 \\
\hline $\begin{array}{l}\text { Playing games as part of the learning experience in class will be } \\
\text { boring }\end{array}$ & .174 & .165 & .137 & -.048 & .276 & .763 \\
\hline Eigenvalue & 10.732 & 3.493 & 2.107 & 1.768 & 1.312 & 1.159 \\
\hline$\%$ of variance explained & 32.521 & 10.585 & 6.385 & 5.359 & 3.975 & 3.512 \\
\hline Cumulative $\%$ & 32.521 & 43.106 & 49.491 & 54.849 & 58.824 & 62.336 \\
\hline Reliability (Crombach alpha) & 0.919 & 0.909 & 0.865 & 0.794 & 0.902 & 0.789 \\
\hline
\end{tabular}




\section{Discussion}

Six factors were identified when students' perceptions of serious games in class were analysed.

Performance and experience consisted of six items and accounted for 32.52 percent of the variance with an eigenvalue of 10.73 . This factor was concerned with the usefulness of serious games. Participants felt that playing serious games as part of the learning experience in class will have a positive impact on their productivity and will motivate them to do more class related work. They strongly believed that their performance, logical thinking and problem solving skills would benefit by playing serious games in class. In general, they were positive that their learning experience and learning would be enhanced.

Ease of use consisted of five items and accounted for 10.59 percent of the variance with an eigenvalue of 3.49 . This factor was concerned with the perception of students that serious games will be easy to play. Participants indicated that it would be easy to learn how to play serious games and how to interact with and control serious games. Navigation seemed not to be problem and they felt positive that they would easily become skillful at playing serious games.

Self-efficacy consisted of seven items and accounted for 6.39 percent of the variance with an eigenvalue of 2.11. This factor was concerned with the self-efficacy of users. Efficacy is defined as the "power or capacity to produce a desired effect" or "the quality of being successful in producing an intended result" (The free dictionary, 20140715). Users have a natural drive towards competence, which is activated by a sense of efficacy (Davis, 1989). If a game is easy to operate the player's level of self-efficacy will increase and so will the user's motivation to persist in accomplishing the task. Thus, attitude and behaviour are impacted by a sense of self-efficacy. Regarding the participant's attitude towards serious games in class, they responded that it would be wise and a good idea to use games to enhance learning in class. They also indicated that the influence of peers would motivate them to use serious games in class. Regarding the participant's behaviour, they indicated that they would like to attend classes where serious games are part of the learning experience and they predicted that they would use serious games if it were available to them.

Help facilitation consisted of seven items and accounted for 5.36 percent of the variance with an eigenvalue of 1.77. This factor was concerned with participants' perceptions of help facilities available when playing serious games in class. This factor revealed that participants felt the need for external help and support. They indicated that they will be able to play serious games in class if someone show them how to play the game first, someone assist in getting started and tell them what to do, and if help is available when needed.

Enjoyment consisted of three items and accounted for 3.98 percent of the variance with an eigenvalue of 1.31 . This factor was concerned with the enjoyment that serious games offer. Fun and entertainment has the ability to motivate people to focus on the activity they perform. They often lose track of time and spend more time on the activity as they anticipated and get so involved in an activity that nothing else seems to matter (Csikszentmihalyi, Larson \& Prescott, 1977). Participants anticipated that serious games in class would be fun, pleasant and enjoyable. The fun and entertainment aspects of serious games could be used as a needed motivation to become immersed into the learning material.

Negativity consisted of two items and accounted for 3.51 percent of the variance with an eigenvalue of 1.16. This factor was concerned with fears or negativity as some of the participants indicated that the use of serious games in class would be frustrating and boring.

\section{Limitation and Implication for Further Research}

A non-probability convenience sampling method was used in a single province in South Africa. The nature of the sampling method thus limited this study. Caution should be exercised when generalising the perceptions of computer science lecturers towards serious games in class to other provinces. Notwithstanding this limitation, this study makes a significant contribution to the knowledge base of the perceptions of computer science students towards the use of serious games in class.

Arising from the results of the study are implications for further research. Extending the study to other universities in other provinces in South Africa and comparing the results may provide a more comprehensive illustration of the perceptions of computer science students towards serious games in class.

\section{Conclusion}

The purpose of this study was to investigate the factors that influence computer science students' perceptions towards serious games in the classroom. The study revealed that computer science students have a positive attitude towards the 
use of serious games in class. The factors that influence students' perceptions in a positive way are performance and experience, ease of use, self-efficacy, help facilitation and enjoyment. One factor, negativity, indicated that some students might be bored and frustrated using serious games in class, was also detected.

\section{References}

Corriveau, J., \& Wei S. (2010). Teaching strategies to millenial students. Proceedings of the International Academic Conference on the Future of Game Design and Technology. ACM, 143-150.

Csikszentmihalyi, M., Larson, R., \& Prescott, S. (1977). The ecology of adolescent activity and experience. Journal of Youth and Adolescence, 6(3), 281-294.

Davis F. D. (1989). Perceived usefulness, perceived ease of use, and user acceptance of information technology. MIS Quarterly, 13(3), 319-340.

Devlin-Scherer R., \& Sardone N. B. (2010). Digital simulation games for social studies classrooms. The clearing house: $A$ Journal of Educational Strategies, Issues and Ideas, 83(4), 138-144. [Online] Available: http://dx.doi.org/10.1080/00098651003774836 (February 19, 2013).

Engenfeldt-Nielsen, S. (2011). Digital solutions for education, "entertain, engage \& educate". Copenhagen, Denmark: Serious Games Interactive.

Gee, J. P. (2008). Getting over the slump: innovation strategies to promote children's learning. Joan Ganz Cooney Center.

Gillespie, M., Derevensky, J., \& Gupta, R. (2007). The utility of outcome expectancies in the prediction of adolescent gambling behaviour. Journal of Gambling Issues, 19, 69-85.

Guillén-Nieto V., \& Aleson-Carbonell M. (2012) Serious games and learning effectiveness: the case of it's a deal! Computers \& Education, 58, 435-448.

Kickmeier-Rust, M. D., \& Albert, D. (2012) Educationally adaptive: balancing serious games. International Journal of Computer Science in Sport, 11 (Special Ed.), 15-28.

Klopfer, E., Osterweil, S., Groff, J., \& Haas, J. (2009). The instructional power of digital games, social networking simulations and how teachers can leverage them. [Online] Available: http://creativecommons.org/licenses/by/3.0 (January 17, 2014).

Kurkovsky, S. (2009). Engaging students through mobile game development. ACM SIGCSE Bulletin, 41(1), 44-48.

Lenhart, A., Madden, M., \& Hitlin, P. (2005). Teens and technology: youth are leading the transition to a fully wired and mobile nation. Pew Internet and American Life Project. [Online] Available: http://www.pewinternet.org/ppf/r/162/report_display.asp (November 12, 2013).

Lieberman, D. A. (2006). What can we learn from playing interactive games? Playing video games: Motives, responses, and consequences, 379-397. [Online] Available: http://ocw.metu.edu.tr/pluginfile.php/2381/mod_resource/content/0/ceit706/ week7/ Lieberman_What\%20-makesplaying.pdf (March 21, 2013).

Nunnally, J. C., \& Bernstein, I. H. (1994). Psychometric theory (3rd ed.). New York: McGraw-Hill.

Papastergiou, M. (2009). Digital game-based learning in high school computer science education: impact on educational effectiveness and student motivation. Computers \& Education, 52, 1-12.

Rodgers, W. (2014). Technology in the classroom. [Online] Available: http://www.shelbyed.k12.al.us/schools/rms/faculty/wrodgers/ technology\%20int/students.html (January 15, 2014).

Rooney, P. (2012). A theoretical framework for serious game design: exploring pedagogy, play and fidelity and their implications for the design process.

Shaffer, D. W. (2005). Epistemic games. Innovate: Journal of Online Education, 1(6).

Smith, R., (2007). Game impact theory: the five forces that are driving the adoption of game technologies within multiple established industries. Games and Society Yearbook.

Stanescu, I. A., Stefan, A., \& Roceanu, I. (2011). Interoperability in serious games. eLearning \& Software for Education.

Stege, L., Van Lankveld, G., \& Spronck P. (2011). Serious games in education. International Journal of Computer Science in Sport, $10(1), 1-9$.

Susi, T., Johannesson M., \& Backlund P. (2007). Serious games: an overview. [Online] Available: http://www.diva-portal.org/smash/ get/diva2:2416/FULLTEXT01.pdf (July 20, 2013).

Sweeny, R. T. (2007). How the new generation of well-wired multitaskers is changing campus culture. Chronical of Higher Education, 53(13). [Online] Available: http://chronicle.com/article/How-the-New-Generation-of/10203 (March 18, 2012).

Szczesna, A. S., Tomaszek, M., \& Wieteska, A. (2011) Settings goals in psychology serious game for preschool children.

The free dictionary. [Online] Available: http://www.thefreedictionary.com/efficacy. (July 20, 2014).

Ulicsak, M., \& Wright, M. (2010). Games in education: serious games. A Futurelab literature review. Futurelab, 1, June. [Online] Available: www.futurelab.org.uk

Westera, W., Nadolski, R. J., Hummel, H. G. K., \& Wopereis, I. G. J. H. (2008). Serious games for higher education: a framework for reducing design complexity. Journal of Computer Assisted Learning, 24, 420-432.

Wikipedia.org. [Online] Available: http://en.wikipedia.org/wiki/Serious_games (March 18, 2012).

Wrzesien, M., \& Alcañiz Raya, M. (2010). Learning in serious virtual worlds: evaluation of learning effectiveness and appeal to students in the E-Junior project. Computers \& Education, 55.

Zikmund, W. G., Babin, B. J., Carr, J. C., \& Griffin, M. (2010). Business research methods. (8th ed.). Southern-Western: Centage Learning.

Zyda, M. (2005). From visual simulation to virtual reality to games. IEEE Computer Society September 2005, 25-32. 